\title{
UJI TOKSISITAS AKUT EKSTRAK KUNYIT PUTIH (Curcuma zedoaria) PADA GINJAL TIKUS WISTAR JANTAN
}

\author{
Joanne Odelia Gani, Fiska Maya Wardhani* ${ }^{* \otimes}$, Erny Tandanu ${ }^{* \star \star}$
}

\begin{abstract}
Abstrak
Indonesia kaya akan keanekaragaman hayati dengan kandungan zat alaminya yang dapat dimanfaatkan sebagai obat herbal di Indonesia. Banyak tanaman tradisional sering digunakan masyarakat dalam mengatasi permasalahan kesehatan, salah satunya yaitu kunyit putih (Curcuma zedoaria). Untuk memenuhi persyaratan keamanan, manfaat, dan standarisasi, ekstrak kunyit putih perlu diuji toksisitas untuk memperkirakan derajat kerusakan yang terjadi pada ginjal. Uji toksisitas akut pada penelitian ini menggunakan tikus Wistar jantan, dibagi ke dalam enam kelompok perlakuan, kemudian diamati gejala toksisitas dalam 24 jam dan dicatat jumlah tikus yang mati. Organ ginjal diambil pada hari ke-15 untuk pengamatan histopatologi. Hasil uji toksisitas akut ekstrak kunyit putih menunjukkan tidak menyebabkan kematian pada tikus, sehingga nilai LD50 semu pada ekstrak kunyit putih adalah $>2000 \mathrm{mg} / \mathrm{kgBB}$ dengan kriteria praktis tidak toksik. Kesimpulan dari penelitian ini adalah tidak ada perbedaan yang signifikan pada histopatologi ginjal seperti pelebaran ruang Bowman dan degenerasi sel tubulus pada dosis ekstrak kunyit putih $2000 \mathrm{mg} / \mathrm{kgBB}$ dengan kelompok lainnya $(\mathrm{p}=0,315)$.
\end{abstract}

Kata kunci: ekstrak kunyit putih, ginjal, toksisitas akut

\section{ACUTE TOXICITY TEST OF WHITE TUMERIC EXTRACT (Curcuma zedoaria) IN MALE WISTAR RAT KIDNEY}

\begin{abstract}
Indonesia is rich in a variety of herbal plants which contain natural substances that can be used as herbal medicines in Indonesia. Numerous traditional plants are often used by the community in overcoming health problems, one of them is white turmeric (Curcuma zedoaria). To qualify the requirements of safety, efficacy, and standardization, white turmeric extract need to be tested for toxicity and assess the damage degree for toxic effects that occurs, especially on the kidney. This acute toxicity test is carried out with male Wistar rats that are divided into six groups, then observes the toxicity symptoms within 24 hours and records the total of dead rats. Kidney organs are retrieved on day $15^{\text {th }}$ for histopathology test. The results of this acute toxicity test of white turmeric extract showed that it did not cause death in rats, so the pseudoLD50 value of white turmeric extract was $>2000 \mathrm{mg} / \mathrm{kgBW}$ and is classified as a practically non-toxic category. The conclusion of this study was that there was no significant difference in renal histopathology such as widening of Bowman's space and tubular cell degeneration at a dose of white turmeric extract $2000 \mathrm{mg} /$ $\mathrm{kgBW}$ with other groups $(\mathrm{p}=0.315)$.
\end{abstract}

Keywords: acute toxicity, kidney, white tumeric extract

* Program Studi Pendidikan Dokter (S1), Fakultas Kedokteran, Universitas Prima Indonesia

** Departemen Histologi, Fakultas Kedokteran, Universitas Prima Indonesia

${ }^{* * *}$ Departemen Farmakologi, Fakultas Kedokteran, Universitas Prima Indonesia

E-mail: fiskamayawardhani@unprimdn.ac.id 


\section{Pendahuluan}

Pemanfaatan tanaman obat dapat digunakan secara langsung maupun melalui berbagai proses ekstraksi sebagai sumber senyawa aktif baru yang memiliki efek farmakologis dan terapeutik. ${ }^{1}$ Indonesia memiliki banyak keanekaragaman hayati dengan kandungan zat alami yang dapat dimanfaatkan sebagai obat herbal, minat penggunaan obat herbal di Indonesia meningkat selama dekade terakhir. ${ }^{2}$ Banyak tanaman yang bisa digunakan masyarakat sebagai obat tradisional untuk mengobati permasalahan kesehatan, salah satunya yaitu kunyit putih (Curucuma zedoaria). Curcuma mengandung $60-70 \%$ karbohidrat, protein 8,6\%, 5-10\% lemak, 3-5\% curcuminoids, 2-7\% serat, $5 \%$ resin dan minyak esensial. ${ }^{3}$

Kurkumin dalam kunyit putih terbukti berguna untuk kondisi inflamasi, sindrom metabolik, nyeri, dan membantu meredakan kondisi inflamasi degeneratif pada mata. Manfaat kurkumin sebagai antioksidan dan antiinflamasi, juga berguna dalam perbaikan histopatologi ginjal. ${ }^{4}$ Terutama saat ginjal terpapar oleh limbah logam yang berbahaya bagi kesehatan tubuh. Hal ini dikarenakan ginjal merupakan jalur utama limbah logam ketika diekskresikan dari tubuh. ${ }^{5}$

Tidak hanya itu, ginjal dapat juga berfungsi mengeluarkan toksin dan zat asing seperti racun hama, zat aditif makanan dan obat-obatan. Ginjal mengembalikan zat yang dibutuhkan ke dalam darah dan mengekskresi zat dari filtrat yang tidak diperlukan melalui urin. Sisa produk metabolisme yang tidak diinginkan ini meliputi urea, kreatinin, asam urat, bilirubin, dan metabolit berbagai hormon. ${ }^{6}$

Menurut penelitian Winarsih et al. (2012) pada pemberian dosis toksik fraksi etil asetat dan hexan ekstrak etanol rimpang kunyit, sebagian sel tubulus ginjal mengalami degenerasi dan nekrosis saat pemeriksaan mikroskopik. Sejalan dengan bertambahnya dosis, degenerasi dan nekrosis sel tubulus yang terjadi semakin berat. Pemberian serbuk kunyit dengan kurkumin pada dosis tertentu tidak menyebabkan perubahan pada ginjal baik secara makroskopik maupun mikroskopik. ${ }^{7}$ Hal ini menunjukkan bahwa senyawa fenolik dalam curcumin beraksi dengan reactive nitrogen species (RNS) dan reactive oxygen species (ROS) karena termasuk salah satu cara curcumin melindungi sel epitel tubulus ginjal dari kerusakan stres oksidatif. ${ }^{8}$

Penelitian ini dilakukan agar memenuhi persyaratan keamanan, manfaat dan standarisasi efek uji toksisitas akut kunyit putih yang diamati melalui gambaran histopatologi ginjal. ${ }^{9}$ Informasi tentang kadar bahaya pada sediaan uji jika dipaparkan pada manusia dapat diperoleh dari hasil data sehingga dosis pemberian dapat ditetapkan demi keamanan manusia. ${ }^{10}$

\section{Bahan dan Metode}

\section{Rancangan Penelitian}

Penelitian eksperimental ini menggunakan jenis rancangan the post test only control group design.

\section{Populasi dan Sampel Penelitian}

Penelitian ini menggunakan 30 ekor tikus galur Wistar jantan. Sampel diambil menggunakan teknik simple random sampling dan memenuhi kriteria yaitu: tikus putih jantan sehat, dengan umur 6-8 minggu dan berat badan $160-200 \mathrm{mg}$.

\section{Variabel Penelitian}

Uji toksisitas akut dengan perlakuan dosis ekstrak kunyit putih ditetapkan sebagai variabel bebas dan gambaran histopatologi ginjal tikus sebagai variabel terikat.

\section{Lokasi Penelitian}

Penelitian dilakukan di Laboratorium Farmakologi dan Laboratorium Histologi, Fakultas Kedokteran, Universitas Sumatera Utara pada bulan April 2021. 
Penelitian ini sudah melewati komisi etik Universitas Prima Indonesia dengan nomor: 046/KEPK/UNPRI/III/2021.

Uji Toksisitas Akut Ekstrak Kunyit Putih terhadap Ginjal Tikus

Bahan uji yang digunakan berasal dari tanaman rimpang kunyit putih yang didapatkan dari UPT Materia Medica Batu, Jawa Timur. Tikus dikelompokkan ke dalam 6 kelompok perlakuan sesuai dosis ekstrak kunyit putih yang diberikan (Gambar 1). Pengamatan secara periodik dalam 24 jam pertama untuk melihat adanya gejala toksisitas dan sehari sekali selama 14 hari seperti sistem pernafasan, somamotor, mata, kulit dan bulu, mukosa, salivasi, kejang, tremor, diare, lemah, tidur, letargi dan koma. Tikus ditimbang kemudian dikorbankan pada hari ke-15. Pembedahan dilakukan untuk mengambil organ ginjal dan dimasukkan ke dalam pot formalin $10 \%$. Pembuatan preparat histopatologi ginjal di Departemen Histologi, Fakultas Kedokteran, Universitas Sumatera Utara menggunakan pewarnaan Hematoxylin Eosin (HE). Setiap kelompok diamati di bawah mikroskop cahaya dengan lima bidang pandang besar yang berbeda menggunakan pembesaran 100x dan 400x. Pengukuran ruang Bowman menggunakan software NOEL. Tingkat kerusakan ginjal dihitung berdasarkan metode skoring histopatologi ginjal pada Tabel $1 .{ }^{11}$

\section{Analisis Data}

Data yang diperoleh dilakukan uji normalitas menggunakan Saphiro-Wilk dan dilanjutkan dengan uji analisis varian (ANOVA) untuk mengetahui kadar toksisitas ekstrak kunyit putih berdasarkan variasi dosis.

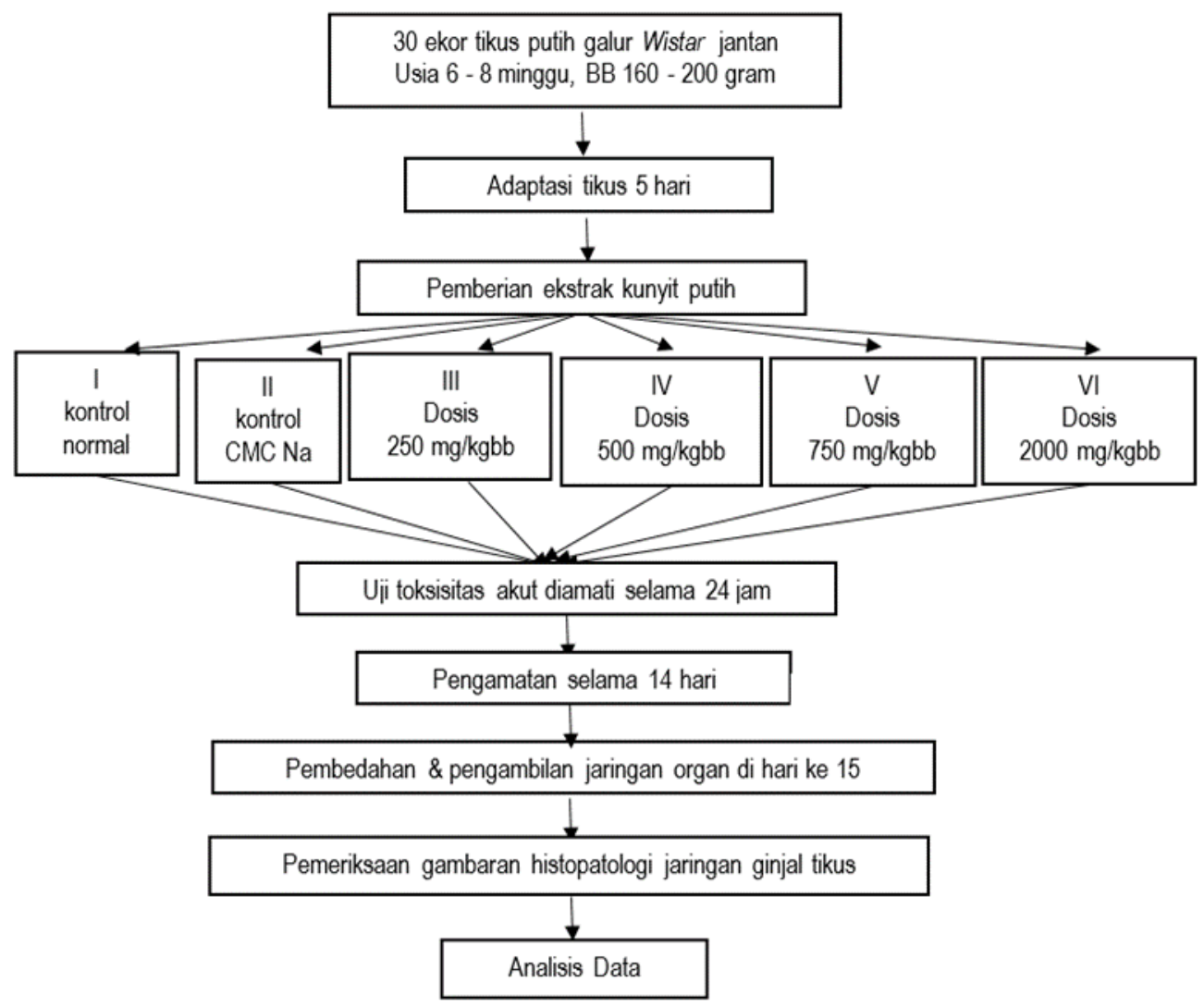

Gambar 1. Diagram alur uji toksisitas akut ekstrak kunyit putih terhadap ginjal tikus 
Tabel 1. Skoring histopatologi ginjal11

\begin{tabular}{cl}
\hline Skor & \multicolumn{1}{c}{ Kriteria Kerusakan } \\
\hline 1 & Tidak terjadi kerusakan jaringan ginjal (pelebaran lumen tubulus, akumulasi sel-sel debris \\
& $\begin{array}{l}\text { dalam lumen, vakuolisasi lumen tubulus, pelebaran ruang bowman, degenerasi, } \\
\text { hiperplasia, kariomegali, dan benda-benda inklusi). }\end{array}$ \\
2 & Bila ditemukan 1-2 kriteria di atas. \\
3 & Bila ditemukan 3-5 kriteria di atas. \\
4 & Bila ditemukan 6-8 kriteria di atas. \\
\hline
\end{tabular}

\section{Hasil}

Dari hasil pengamatan berat badan ratarata, didapatkan adanya perbedaan bermakna berat badan awal dan akhir antara kelompok II dan IV $(p<0,05)$. Pada kelompok I, III, V dan VI tidak terdapat perbedaan bermakna antara berat badan awal dan akhir $(p>0,05)$ (Tabel 2). Hasil pengamatan yang dilakukan selama 14 hari, kulit, bulu dan mata tikus tampak normal. Tikus tidak mengalami letargi, konvulsi, tremor, diare dan mati pada minggu pertama. Begitu juga pada minggu kedua, tikus tidak mengalami gejala-gejala toksik. Pergerakkan atau aktivitas tikus pada akhir minggu kedua meningkat sehingga tikus tampak lebih semangat (Gambar 2).
Hasil pengamatan histopatologi terhadap kelompok perlakuan I, II, III, dan IV tidak dijumpai kelainan histopatologi ginjal. Pada kelompok perlakuan $\mathrm{V}$ dan $\mathrm{VI}$ didapatkan degenerasi tubulus yang ringan dan pelebaran Bowman space yang ringan pada kelompok VI dapat dilihat pada Gambar 3.

Hasil rerata skor histopatologi ginjal masing-masing kelompok perlakukan didapatkan perubahan yang minimal berupa degenerasi tubulus yang ringan dan pelebaran Bowman space yang tidak signifikan terutama pada kelompok $\mathrm{V}$ dan $\mathrm{VI}$ (Tabel 3). Hasil uji Saphiro-Wilk histopatologi ginjal menunjukkan data berdistribusi normal $(p>0,05)$. Dari hasil uji ANOVA, tidak ditemukan adanya perbedaan histopatologi ginjal yang signifikan antar kelompok $(p=$ 0,315).

Tabel 2. Perbandingan rata-rata berat badan awal dan akhir tikus setelah 14 hari

\begin{tabular}{lccc}
\hline \multicolumn{1}{c}{ Kelompok } & Berat Badan Awal (gram) & Berat Badan Akhir (gram) & p value \\
\hline I (kontrol normal) & $154,60 \pm 7,266$ & $165,80 \pm 12,617$ & 0,134 \\
II (kontrol CMC Na) & $164,25 \pm 21,639$ & $181,00 \pm 20,445$ & $0,004^{*}$ \\
III (250 mg/kgBB) & $196,00 \pm 18,762$ & $186,00 \pm 21,743$ & 0,238 \\
IV (500 mg/kgBB) & $173,00 \pm 22,858$ & $181,20 \pm 20,873$ & $0,044^{*}$ \\
V (750 mg/kgBB) & $164,80 \pm 20,657$ & $171,00 \pm 17,479$ & 0,419 \\
VI (2000 mg/kgBB) & $188,40 \pm 21,408$ & $191,60 \pm 27,098$ & 0,493 \\
\hline
\end{tabular}

Keterangan: * Sig $p<0,05$ 


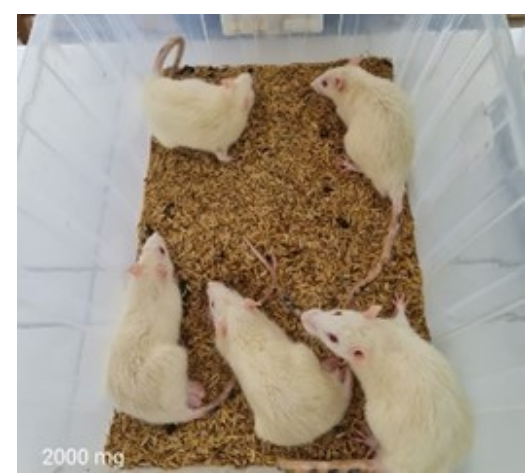

Gambar 2. Kelompok tikus perlakuan dosis $2000 \mathrm{mg} / \mathrm{kgBB}$ pada minggu kedua Keterangan: Aktivitas tikus meningkat terutama pada dosis $2000 \mathrm{mg} / \mathrm{kgBB}$

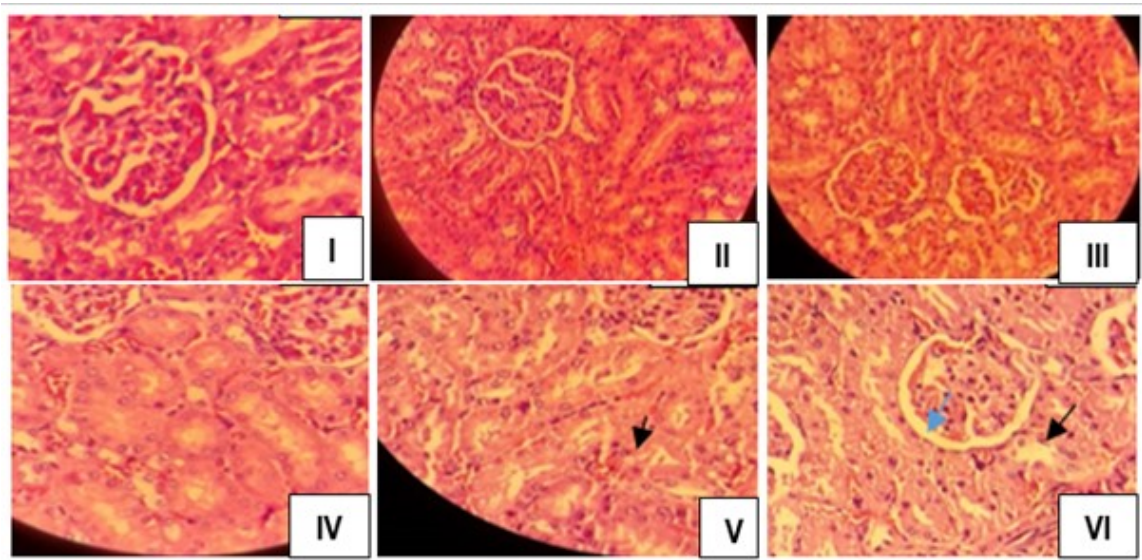

Gambar 3. Histopatologi ginjal tikus pada tiap kelompok perlakuan Keterangan: Degenerasi tubulus $(\rightarrow)$, pelebaran ruang bowman $(\rightarrow)$

Tabel 3. Rata-rata skor histopatologi ginjal

\begin{tabular}{lc}
\hline \multicolumn{1}{c}{ Kelompok } & Rata-rata \pm SD \\
\hline I (kontrol normal) & $0,00 \pm 0,000$ \\
II (kontrol CMC Na) & $0,00 \pm 0,000$ \\
III $(250 \mathrm{mg} / \mathrm{kgBB})$ & $0,33 \pm 0,577$ \\
IV $(500 \mathrm{mg} / \mathrm{kgBB})$ & $0,67 \pm 1,155$ \\
V $(750 \mathrm{mg} / \mathrm{kgBB})$ & $1,00 \pm 1,000$ \\
VI $(2000 \mathrm{mg} / \mathrm{kgBB})$ & $1,33 \pm 1,155$ \\
\hline
\end{tabular}

\section{Pembahasan}

Uji toksisitas akut merupakan suatu uji praklinik penting untuk menentukan efek toksik suatu senyawa yang terjadi setelah pemberian dosis tunggal dalam waktu 24 jam dan akan diperoleh data kuantitatif yaitu LD50 (lethal dose 50$).{ }^{10}$ Dari hasil uji toksisitas akut ekstrak kunyit putih, tidak ditemukan adanya gejala toksisitas dan kematian pada tikus dosis $250 \mathrm{mg} / \mathrm{kgBB}$ hingga dosis 2000 $\mathrm{mg} / \mathrm{kgBB}$. Jika tidak ada kematian, nilai $L D_{50}$ tidak dapat dihitung. Maka penentuan nilai $\mathrm{LD}_{50}$ diambil dosis tertinggi dan dinyatakan dengan $L D_{50}$ semu atau bukan $L D_{50}$ yang sesungguhnya. ${ }^{12}$ 
Bila tidak ditemukan kematian hewan uji pada dosis tertinggi, maka sediaan uji tergolong kriteria praktis tidak toksik. ${ }^{13}$ Sehingga didapat nilai LD50 semu pada ekstrak kunyit putih $>2000 \mathrm{mg} / \mathrm{kgBB}$.

Pengamatan berat badan tikus dilakukan untuk melihat dampak perubahan berat badan yang timbul selama 14 hari setelah ekstrak diberikan. Kondisi hewan uji yang sakit ataupun menderita setelah konsumsi ekstrak ditandai dengan penurunan berat badan lebih dari $20 \%$ atau $25 \%$ yang umumnya diikuti penurunan ataupun tidak mengkonsumsi makanan selama 7 hari atau lebih. 12 Namun, setelah diamati 14 hari, hewan uji tetap mengkonsumsi makanan dan tidak ditemukan sakit atau derita setelah pemberian ekstrak. Sebaliknya, pergerakan atau aktivitas hewan uji meningkat sehingga tikus tampak lebih semangat pada akhir minggu kedua.

Secara keseluruhan, pemberian kunyit putih hingga dosis $2000 \mathrm{mg} / \mathrm{kgBB}$ juga aman terhadap ginjal karena perubahan histopatologi yang terjadi bersifat ringan dan tidak signifikan. Perubahan mikroskopis seperti pertambahan degenerasi tubulus yang minimal seiring peningkatan dosis, tidak banyak ditimbulkan apabila ekstrak kunyit putih diberikan secara akut dengan dosis rendah. ${ }^{7}$ Penelitian sebelumnya menunjukkan aktivitas antiinflamasi dan antioksidan kunyit putih bermanfaat baik dalam mengatasi penyakit ginjal maupun saat ginjal terpapar zat toksik. Efek nefroprotektif komponen fenolik dalam curcumin mampu mengurangi stres oksidatif dengan menjaga tubulus ginjal dari radikal bebas dan meningkatkan sistem antioksidan dalam tubuh. ${ }^{14}$ Manfaat ini paling baik didapatkan ketika curcumin dikombinasikan dengan piperin yang meningkatkan bioavibilitas secara signifikan. Sehingga pemberian dosis kunyit relatif rendah bermanfaat dan aman dikonsumsi juga bagi orang yang tidak sakit. ${ }^{4}$

Pelebaran ruang Bowman pada pemberian ekstrak kunyit putih dosis 2000 $\mathrm{mg} / \mathrm{kgBB}$ disebabkan oleh penurunan jumlah ataupun ukuran jaringan sel (atrofi glomerulus) yang bisa terjadi karena adanya perlambatan kemampuan proses penyaringan, sehingga sel darah maupun protein lolos bersamaan urin dan tertimbun pada tubulus. ${ }^{15}$ Proses degenerasi timbul oleh proses kerusakan tubulus ginjal, terutama saat akumulasi ekstrak kunyit puth yang tinggi pada tubulus proksimal secara terus menerus pada absorbsi dan sekresi. ${ }^{16}$ Saat konsentrasi suatu senyawa yang diberikan semakin tinggi, ginjal akan mulai memperlihatkan respons berupa degenerasi tubulus pada gambaran mikroskopis. Degenerasi ditandai adanya kondisi gangguan metabolik dimana sel mengalami kehilangan sruktur normalnya sehingga menimbulkan penimbunan bahan-bahan baik secara ekstraseluler maupun intraseluler. Degenerasi bersifat sementara dan dapat pulih kembali menjadi normal jika pemberian ekstrak dihentikan. ${ }^{17}$ Pemberian ekstrak bila dilanjutkan dalam waktu yang lama, degenerasi dapat berlanjut menjadi nekrosis dan menyebabkan penurunan fungsi ginjal. ${ }^{16}$ Maka dari itu perlu dilakukan pengujian toksisitas pemberian ekstrak kunyit putih lebih lanjut terhadap ginjal dalam periode yang lebih lama.

\section{Kesimpulan}

Kesimpulan dari penelitian ini adalah tidak ada perbedaan yang signifikan pada histopatologi ginjal seperti pelebaran ruang Bowman dan degenerasi sel tubulus pada dosis ekstrak kunyit putih $2000 \mathrm{mg} / \mathrm{kgBB}$ dengan kelompok lainnya.

\section{Daftar Pustaka}

1. Subositi D, Wahyono S. Study of the Genus Curcuma in Indonesia Used as Traditional Herbal Medicines. Biodiversitas. 2019; 20(5):1356-61. 
2. Sumantri AW. Uji Aktivitas Sitotoksik dari Tumbuhan Temu Putih (Curcuma zedoaria) Asal Kabupaten Ogan Komering Ulu. J Chem Inf Model. 2019; 53(9):168999.

3. Wardhani FM, Chiuman L, Ginting CN, Ginting SF, Nasution AN. Efek Ekstrak Kunyit Putih (Curcuma zedoaria) sebagai Nefroprotektor pada Tikus Putih Jantan Galur Wistar yang Diinduksi Tembaga. J Indones Med Assoc. 2019; 69(8):258-66.

4. Hewlings S, Kalman D. Curcumin: A Review of Its Effects on Human Health. Foods. 2017; 6(10):92.

5. Avila-Rojas SH, Lira-León A, AparicioTrejo OE, Reyes-Fermín LM, PedrazaChaverri J. Role of Autophagy on Heavy Metal-Induced Renal Damage and the Protective Effects of Curcumin in Autophagy and Kidney Preservation. Med. 2019; 55(7):14-7.

6. Guyton AC, Hall J. Buku Ajar Fisiologi Kedokteran. Edisi ke-12 Jakarta: EGC. 2014.

7. Winarsih W, Wientarsih I, Sulistyawati NP, Wahyudina I. Uji Toksisitas Akut Ekstrak Rimpang Kunyit pada Mencit: Kajian Histopatologis Lambung, Hati dan Ginjal. $J$ Vet. 2012; 13(4):402-9.

8. Nasri $H$, Abedi-gheshlaghi $Z$, Rafieiankopaei M. Curcumin and Kidney Protection; Current Findings and New Concepts. Acta Persica Pathophysiol. 2016; 1(1):1-6.

9. Mulyani $T$, Ida Julianti C, Sihombing R. Tinjauan Pustaka: Teknik Pengujian Toksisitas Teratogenik pada Obat Herbal. J Farm Udayana. 2020; 9(1):31.

10. BPOM. Peraturan Kepala Badan Pengawas Obat dan Makanan Republik Indonesia Nomor 7 Tahun 2014. Tentang
Pedoman Uji Toksisitas Nonklinik Secara Vivo. 2014. HIm. 66-8.

11. Qodar TS, Dwi Wisudanti D, Munawaroh Aziz A. Efek Pemberian Tepung Kedelai terhadap Gambaran Histopatologi Ginjal Tikus Wistar yang Diinduksi Diazinon. eJournal Kedokt Indones. 2019; 7(1):6671.

12. Sulastra CS, Khaerati KKK, Ihwan. Toksisitas Akut dan Lethal Dosis (LD50) Ekstrak Etanol Uwi Banggai Ungu (Dioscorea alata L.) pada Tikus Putih (Rattus norvegicus). J Ilm Medicam. 2020; 6(1):10-4.

13. Sianturi S, Febriani A, Manalu MADR. Uji Toksisitas Akut Ekstrak Etanol 70\% Daun Tegining Ganang (Cassia planisiliqua Burm.F.) Terhadap Mencit Jantan (Mus musculus L.). Pharmauho J Farm Sains, dan Kesehat. 2020; 5(2):1-8.

14. Safi $H$, Kafeshani M, Mansouri $E$, Rafieian -kopaei M, Nasri H. Impact of Various Doses of Curcumin on Contrast Media Induced Nephrotoxicity: a Histopathological and Biochemical Study. 2018;7(x):1-5

15. Maliza R, Tofrizal A, Setiawan $H$. Uji Toksisitas Subkronis Ekstrak Metanol Kulit Buah Kopi Arabika (Coffea arabica I.) pada Ginjal Mencit (Mus musculus I.) Galur BALB/c. Semin Nas Bioteknol VI. 2021;(January):137-46.

16. Kamaliani BR, Setiasih NLE, Winaya IBO. Histopathological Kidney Overview of Experimental Diabetes Mellitus Wistar Rats Given Ethanol Extract of Moringa Leaf. Bul Vet Udayana. 2019; (21):71.

17. Almunawati, Budiman $H$, Aliza D. Histopatologi Ginjal Tikus Putih (Rattus norvegicus) yang Diinjeksi Formalin. J IIm Farm. 2017; 1(3):424-31. 